\title{
The Pianist (Śmierć miasta)
}

Author: Władysław Szpilman, pseudonym Al Legro

First Published: 1946

Translations: among others German (Das wunderbare Überleben - Warschauer Erinnerungen 1939-1945, 1998); English (The Pianist: The Extraordinary Story of One Man's Survival in Warsaw, 1939-45, 1999); French (Le Pianiste: L'extraordinaire destin d'un musicien juif dans le ghetto de Varsovie, 1939-1945, 2000); Czech (Pianista, 2003); Portuguese (Brazil) (O Pianista, 2007); Spanish (El Pianista del Gueto de Varsovia, 2000); Russian (Pianist. Varšavskije dnevniki 1939-1945, 2003).

Film Adaptation: Miasto neujarzmione (Unvanquished City), feature film, screenplay Jerzy Andrzejewski, Jerzy Zarzycki, film director Jerzy Zarzycki, premiered 1950; Le Pianiste (The Pianist), feature film, screenplay Ronald Harwood, film director Roman Polanski, premiered 2002.

About the Author: Władysław Szpilman (1911-2000) was a Polish pianist and composer of Jewish descent who received worldwide renown when Roman Polanski adapted his work The Death of a City - an autobiographical account of his survival - for the film The Pianist (2002). Szpilman, who was a musician by profession - and a composer and pianist by heart -, did not consider himself a writer. Indeed, he had already become a celebrated pianist following his stage debut in 1932, and subsequently made a name for himself as a composer of classical and popular music. From 1935 until the outbreak of World War II, he worked for Polish Radio performing popular music for piano. By chance, and with the help of an unknown Jewish policeman, Szpilman was able to avoid deportation, unlike the other members of his family, who were deported to Treblinka and did not survive. Szpilman was then conscripted for forced labour in construction work, during which he also helped smuggle weapons to the Warsaw Ghetto for the imminent uprising. After his escape from the ghetto in 1943, he lived in hiding until the end of July 1944, receiving assistance from Poles (including the composer Witold Lutosławski). In November, 1944, Wehrmacht Captain Wilm Hosenfeld discovered him hiding in the ruins of Warsaw, close to starvation, and helped him to survive. After the war Szpilman continued his career at Polish Radio and served as head of the Popular Music Department (1945-1963). In 1961, Szpilman created the prestigious International Song Festival in Sopot, and in 1963 founded the famous Warsaw Piano Quintet. Szpilman is buried in Powązki Military Cemetery in Warsaw. Polish Radio's Studio 1 was named after him, and on 4 December 2011 a commemorative plaque to Szpilman was unveiled in Warsaw.

Ә Open Access. (C) 2021 Hans-Christian Trepte, published by De Gruyter. (c) BY-NC-ND This work is licensed under a Creative Commons Attribution-NonCommercial-NoDerivatives 4.0 License. https://doi.org/10.1515/9783110671056-077 


\section{Content and Interpretation}

Szpilman's book - a picture of life in the Warsaw ghetto on a broad canvas - gives the reader a deeper understanding of what was going on behind ghetto walls, including a Jewish resistance movement that sought to protect the dignity of ghetto inhabitants and that culminated in the Warsaw Ghetto Uprising. Densely written in plain, diaristic, almost emotionless prose, Szpilman's autobiographical narrative evokes a strange mix of despair and hope. Notably lacking any tone of indignation or anger, Szpilman's writing demonstrates a sharp eye for detail, and for characters who refuse to give in to self-pity or sanctimonious behaviour, recording life rather as a function of his inquiry into human dignity and dispassion.

The diary is chronologically structured with concise, highly evocative, often touching descriptions, from the creation of the Warsaw Ghetto and life within the ghetto, to the Umschlagplatz, the Warsaw Uprising, and the death of the city: "a city of rubble and ashes under which [...] the bodies of hundreds of thousands of murdered victims lay buried, rotting in the warmth of these late autumn days and filling the air with a dreadful stench" (Szpilman, 1999, p. 167). Szpilman's diary is characterised by realistic descriptions, of the Polish-Jewish pedagogue Janusz Korczak, for example, who had been given an opportunity to escape deportation to Treblinka, but instead chose to stay with the children of his orphanage all the way to the gas chambers. According to his account, "Korczak told the orphans they were going to the countryside, so they ought to be cheerful. [...] The little column was led by an SS man who loved children, as Germans do, even those he was about to see on their way to the next world. He wanted to ease things for them" (p. 95). In another episode from the diary, Szpilman describes his encounter with his rescuer, Wilm Hosenfeld, telling him it is music that has helped him survive - or as Szpilman tells him, "I am... I was a pianist" (p. 96). "With Chopin's 'Ballade $\mathrm{m} 1$ in $\mathrm{G}$ minor, Op. 23,' the pianist 'disarms' the Nazi, so moved by his playing” (Kerner, 2011, p. 73). In spite of surviving his ordeal, Szpilman declines to conclude his memoir on a happy note. The protagonist walks the streets of an abandoned and totally devastated city: "A stormy wind rattled the scrap-iron in the ruins, whistling and howling through the charred cavities of the windows. Twilight came on. Snow fell from the darkening, leaden sky" (Szpilman, 1999, p. 221).

Szpilman's diaries became the basis for Roman Polanski's renowned film adaptation The Pianist. The Film Academy "appreciated the fate that befell my father, the total degradation of a well-known artist under war conditions," said Szpilman's son Andrzej. The film won three Oscars: for Best Director, Best Actor, and Best Adapted Screenplay.

\section{Main Topics and Problems}

The first edition of Szpilman's diary, The Pianist: The Extraordinary True Story of One Man's Survival in Warsaw, 1939-45, underwent extensive censorship and expurgation, removing all references to the participation of Ukrainians and Lithuanians in 
the persecution and extermination of Jews, as well as specific aspects of Szpilman's language, including any expressions deemed to be anti-Polish (the pejorative epithet shmaltsovnik, for example). In the original introduction, Jerzy Waldorff states that he himself had "written the story as told by Szpilman" (Kuhiwczak, 2007, p. 70), and the decision to credit Szpilman directly as the author was made by the publishing house. An excerpt of the diary preceded the publication of the book edition as Szpilman's Memoirs (Pamiętnik Szpilmana) in a 1946 issue of the weekly magazine Przekrój. "Directly after the war it was impossible to publish a book in Poland which presented a German officer as a brave and helpful man”, writes Wolf Biermann in his epilogue to the German edition, and "Szpilman found himself obliged to pretend that his rescuer Wilm Hosenfeld was Austrian” (Biermann, 2011, p. 211). Later the diary was ignored, or assigned out of print status by its publishers, because it "contained too many painful truths about the collaboration of defeated Russians, Poles, Ukrainians, Latvians and Jews with the German Nazis” (p. 211). Polish writers Jerzy Andrzejewski and Czesław Miłosz wrote a screenplay named Warsaw Robinson (Robinson Warszawski), based on the book, which, like the diary itself, faced extensive censorship and expurgation. Szpilman's story was also the basis for an early film adaptation, a censored version of which was finally released in 1950 as Unvanquished City (Miasto nieujarzmione).

For decades, Szpilman's account of his traumatic wartime experience and miraculous survival did not gain acceptance outside Poland, although Szpilman was known to be an accomplished pianist and chamber musician, with more than two thousand concert appearances in the West. It was his friend, the famous pianist Artur Rubinstein, who first sought the interest of Western publishers in the 1970s, but his efforts were unsuccessful. Finally Szpilman's son Andrzej asked the East German dissident singer and songwriter Wolf Biermann to support an edition of his father's diary in Germany, which would eventually be released in 1998 with an epilogue by Biermann. The English edition of Szpilman's work, translated by Anthea Bell, was probably based on the German, and includes excerpts from Wilm Hosenfeld's diary (1942-1944), as well as Biermann's epilogue. A new Polish edition, Pianista: Warszawskie Wspomnienia 1939-1945, was published in 2000 without Waldorff's stylistic interventions. The novel remained at first place 2001-2003 on the bestseller list of the Polish newspaper Rzeczpospolita. At the Manchester International Festival in 2007, passages from Szpilman's books were recited to accompaniment by pianist Mikhail Rudy. It was only in 1950 that Szpilman discovered the name and identity of his "good enemy", Wilm Hosenfeld, who died two years later in a Stalingrad prisoner of war camp.

\section{Cited Works}

Biermann, W. (2011). Afterword. In: W. Szpilman, The Pianist. New York: Picador, pp. 211-212. Kerner, A. (2011). Film and the Holocaust. New York: Bloomsbury Publishing, pp. 72-74. Kuhiwczak, P. (2007). The Grammar of Survival: How Do We Read Holocaust Testimonies? In: M. Salama-Carr, ed., Translating and Interpreting Conflict. 
Amsterdam, New York: Rodopi, pp. 61-73. Szpilman, W. (1999). The Pianist: The Extraordinary True Story of One Man's Survival in Warsaw, 1939-45. New York: Picador USA.

\section{Further References}

Applebaum, A. (1999). Playing at Survival in Warsaw. Evening Standard, 14.05., p. 12. Ebbrecht, T. (2011). Geschichtsbilder im medialen Gedächtnis. Filmische Narrationen des Holocaust. Bielefeld: transcript. Engelking, B., Leociak, J. (2009). The Warsaw Ghetto: A Guide to the Perished City. New Haven, London: Yale University Press. Ensor, D. (1985). The Pianist Hero - Wladyslaw Szpilman. Available at: https://www.youtube.com/ watch?v=_vb9c1NxGdg [Accessed: 20.02.2020]. Lichtblau, K. (2018). Wymazywanie autora/autorów. Wspomienia Władysława Szpilmana. In: J. Brejdak., D. Kacprzak et al., eds., Adlojada: Prawo i Kultura, vol. 4, pp. 219-226. Li Powell, T. (2008). The Pianist. In: J. K. Roth, ed., Holocaust Literature, vol. 2. Pasadena: Salem Press, pp. 411414. Maeck, S. (2015): Offizier Wilm Hosenfeld. Der Nazi, der Juden und Polen rettete. Spiegel online, 23.11., available at: https://www.spiegel.de/geschichte/der-pianistdie-wahre-geschichte-hinter-dem-film-a-1058479.html [Accessed: 19.02.2020]. Vinke, H. (2015). „Ich sehe immer den Menschen vor mir“. Das Leben des deutschen Offiziers Wilm Hosenfeld. Zürich: Arche. Wolff, K. (1984). Hiob 1943. Ein Requiem für das Warschauer Ghetto. Berlin: Evangelische Verlagsanstalt. Zapała-Kraj, M. (2018). The Horrors of Holocaust in the View of Literary Translation: The Mechanisms and Principles of Literary Translation in The Pianist by Wladyslaw Szpilman. Available at: https://www.grin.com/document/470996 [Accessed: 19.02.2020].

HCT 